\title{
The Effect of Depolarization on Expression of the Human Proenkephalin Gene Is Synergistic with CAMP and Dependent upon a cAMP-Inducible Enhancer
}

\author{
T. Van Nguyen, ${ }^{1,2,4}$ Linda Kobierski, ${ }^{1,6}$ Michael Comb, ${ }^{1,3,5,6}$ and Steven E. Hyman ${ }^{1,2,4,6}$ \\ 'Molecular Neurobiology Laboratory and Departments of ${ }^{2}$ Psychiatry and ${ }^{3}$ Neurology, Massachusetts General Hospital, \\ Boston, Massachusetts 02114, and Departments of ${ }^{4}$ Psychiatry and ${ }^{5}$ Neurology, and the PProgram in Neurosciences, \\ Harvard Medical School, Boston, Massachusetts 02115
}

\begin{abstract}
Membrane depolarization is a critical component of neural signaling; in recent years there also has been a great deal of evidence that membrane depolarization can regulate neural gene expression. Therefore, excitatory neurotransmission may be an important mechanism of neural plasticity. We have investigated the intracellular pathways and DNA regulatory elements through which membrane depolarization activates expression of the neural gene encoding human proenkephalin. In PC12 and C6-glioma cells, depolarizationinduced expression of a transfected proenkephalin fusion gene was proportional to extracellular calcium concentration and was inhibited by verapamil. Activation of the gene by $\mathrm{KCl}$-induced depolarization or the calcium ionophore $\mathrm{A23187}$ was dependent upon and synergistic with CAMP in PC12 and C6-glioma cells, but neither depolarization nor treatment with A23187 affected CAMP levels. Trifluoperazine and W7 inhibited depolarization-induced gene expression but did not affect expression induced by the adenylyl cyclase activator forskolin. At the level of the DNA, depolarization-induced activation is conferred on the proenkephalin gene by a previously characterized CAMP-inducible enhancer. Multiple copies of a single component element of that enhancer, containing the CGTCA sequence motif characteristic of CAMP regulatory elements, can reconstitute the entire repertoire of responses to both CAMP and depolarization. These data suggest a model in which membrane depolarization activates gene expression through a calcium-dependent pathway, potentially involving calmodulin, and in which the transcriptional responses to both CAMP and calcium are transduced by the same DNA element.
\end{abstract}

The regulation of neural gene expression by synaptic activity and membrane depolarization is well documented (Black et al., 1985; Greenberg et al., 1986; Kley et al., 1986; Morgan and Curran, 1986). One of the best-studied neural genes in models of regulation by synaptic activity and depolarization is the proenkephalin gene. In primary cultures of bovine adrenal chro-

Received Dec. 29, 1989; revised Apr. 13, 1990; accepted Apr. 17, 1990.

This work was supported by NIH Grants MH44160 01 and DK01410-04 to S.E.H. and by a grant from the Juvenile Diabetes Foundation. We thank Joe Pearlberg, who developed the C6-D2 and PC12-F3 lines.

Correspondence should be addressed to Steven E. Hyman, Molecular Neurobiology Laboratory, Massachusetts General Hospital, CNY 6, 149, 13th Street, Charlestown, MA 02129.

Copyright (C) 1990 Society for Neuroscience $0270-6474 / 90 / 082825-09 \$ 03.00 / 0$ maffin cells, proenkephalin mRNA levels have been shown to increase in response to nicotinic stimulation (Eiden et al., 1984), K - or veralridine-induced depolarization (Kley et al., 1986, 1987; Waschek et al., 1987), and calcium ionophores (Kley, 1988). High-frequency electrical stimulation increases proenkephalin mRNA levels and decreases prodynorphin mRNA levels in the rat hippocampus (Morris et al., 1988). Seizures induced by small dentate gyrus hilus lesions have been shown to produce large increases in proenkephalin mRNA in the entorhinal cortex (White and Gall, 1987) and to increase levels of enkephalin immunoreactivity and decrease levels of dynorphin immunorcactivity in the mousc hippocampal mossy fiber system (Gall, 1988). The proenkephalin gene is also regulated by neural activity in rat adrenals. It has been reported that rat adrenal proenkephalin mRNA levels are increased by splanchnic nerve activation (Kanamatsu et al., 1986; Fischer-Colbrie et al., 1988). However, it has been reported that, after denervation (Kilpatrick et al., 1984) or explantation of rat adrenals, proenkephalin mRNA levels also increase, and that in the explants, this increase is suppressed by $\mathrm{K}^{+}$or veratridine ( $\mathrm{La} \mathrm{Gam}$ ma et al., 1985, 1988). The reasons for these discrepant results in rat adrenals are unclear but may reflect the involvement of undetected polysynaptic pathways.

Although a great deal is known about the molecular mechanisms by which cAMP regulates neural gene expression (Comb et al., 1986; Montminy et al., 1986; Lewis et al., 1987; Hyman et al., 1988), relatively little is known about the mechanisms by which membrane depolarization produccs transcriptional effects. The best studied gene to date is proto-oncogene c-fos, for which a calcium-responsive DNA element has been identified (Sheng et al., 1988; Bartel et al., 1989). We therefore examined the mechanisms involved in depolarization-induced expression of the human proenkephalin gene. Experiments were performed using rat pheochromocytoma cells (PC12) and rat C6-glioma cells stably transfected with the proenkephalin fusion plasmid pENKAT-12 (Comb et al., 1986) and derivatives. pENKAT12 contains human proenkephalin genomic sequences spanning nucleotides -193 to +70 with respect to the transcription start site, fused to the bacterial chloramphenicol acyltransferase (CAT) transcription unit, and approximately 1 kilobase $(\mathrm{Kb})$ of proenkephalin $3^{\prime}$ flanking sequence. CAT activity derived from pENKAT-12 has previously been shown to correspond to correctly initiated transcription from the human proenkephalin promoter (Comb et al., 1986). C6-glioma and PC12 cells were used because both cell lines have voltage sensitive calcium 
channels (Miller, 1987) and depolarize in response to high concentrations of extracellular $\mathrm{K}^{+}$. Here, we show that depolarization-induced activation of proenkephalin gene expression is mediated by calcium and possibly calmodulin and is synergistic with cAMP. In addition, we show that regulation of gene expression by calcium and cAMP can converge on a single DNA element.

\section{Materials and Methods}

Cell culture. PC1 2 cells were grown in Dulbecco's modification of Eagle's medium (DMEM), supplemented with $10 \%$ fetal bovine serum and $5 \%$ horse serum; C6-glioma cells were grown in DMEM supplemented with $5 \%$ fetal bovine serum and $5 \%$ newborn calf serum (Sigma). The PC12F3 and C6-D2 lines were produced by cotransfecting $3.5 \times 10^{6} \mathrm{PC} 12$ cells or $8 \times 10^{5} \mathrm{C} 6$-glioma cclls in a $10-\mathrm{cm}$ dish with $20 \mu \mathrm{g}$ pENKAT12 and $5 \mu \mathrm{g}$ pRSVNeo (Gorman et al., 1983), a plasmid that confers resistance to the antibiotic G418. Transfections were performed by $\mathrm{CaPO}_{4}$ precipitation of DNA as previously described (Howard, 1983). Forty-eight hr after transfection, the media was supplemented with 500 $\mu \mathrm{g} / \mathrm{ml} \mathrm{G418.} \mathrm{Under} \mathrm{these} \mathrm{conditions,} 25-50 \%$ of the G418-resistant colonies expressed the unselected pENKAT-12 plasmid. Individual colonies were isolated and grown in microtiter wells. Media was assayed for CAT activity, and single colonies that showed a response to cAMP were expanded.

CAT assays. For CAT assays, $2 \times 10^{5} \mathrm{PC1} 2-\mathrm{F} 3$ cells or $1 \times 10^{5} \mathrm{C} 6-$ D2 or C6-Cre2.2 cells were plated into each well of a 24 -well plate 16 $\mathrm{hr}$ before adding regulators. After a 6 -hr treatment with regulators, the cells were washed with ice-cold phosphate-buffered saline (PBS), overlaycd with $100 \mu \mathrm{l}$ lysis buffcr containing $0.25 \mathrm{M}$ Tris (pH, 7.5) and $0.5 \%$ $(\mathrm{v} / \mathrm{v})$ Triton, and titurated up and down. The lysate was transferred to a microfuge tube and pelleted for $10 \mathrm{~min}$. The supernatant was assayed for CAT activity by incubating $20 \%$ of the extract with a cocktail of 2.5 $\mu \mathrm{Ci} / \mathrm{ml}{ }^{14} \mathrm{C}$-chloramphenicol $(54 \mathrm{mCi} / \mathrm{mmol}$; Amersham), $0.5 \mathrm{mM}$ butyryl coenzyme A (Pharmacia), and $2.5 \%$ glycerol in $0.25 \mathrm{M}$ Tris $(\mathrm{pH}$, $7.5)$ in a total reaction volume of $50 \mu \mathrm{l}$ for $2 \mathrm{hr}$ at $37^{\circ} \mathrm{C}$. Reactions were terminated with a 2:1 mixture of pristane : xylenes (obtained from $\mathrm{Al}-$ drich and Baker, respectively). The butyrylated chloramphenicol extracted into the organic (upper) phase was counted in scintillation fluid (modified from Seed and Sheen, 1988). Protein assays were initially performed by the method of Lowry et al. (1951) to normalize results, but the protein concentrations did not vary significantly from well to well.

cAMP assays. cAMP assays were carried out using a kit assay (Amersham) based on the competition between unlabeled cAMP (from samples) and a fixed quantity of tritium-labeled cAMP for binding to a protein that has a high specificity and affinity for cAMP (Brown et al., 1972). Sixteen hours before adding regulators, $1 \times 10^{6} \mathrm{PC} 12-\mathrm{F} 3$ cells or $5 \times 10^{5} \mathrm{C} 6-\mathrm{D} 2$ cells were plated into a $6-\mathrm{cm}$ dish. After treatment with regulators for selected times, cells were washed twice with ice-cold PBS and harvested in $1.1 \mathrm{ml}$ ice-cold PBS, of which $1 \mathrm{ml}$ was for cAMP determination and $100 \mu$ l for protein determination by the method of Lowry et al. (1951). The cells to be assayed for cAMP were recovered by a 1 -min spin, then sonicated in $150 \mu l$ ethanol. The samples were allowed to stand at room temperature for $5 \mathrm{~min}$ to coagulate protein, and following a 5-min spin, the supernatant was transferred to a new microfuge tube and dried under vacuum. The residue was dissolved in $200 \mu \mathrm{l} 50 \mathrm{~mm}$ Tris-Cl buffer (pH, 7.5) containing $4 \mathrm{~mm}$ EDTA. After a 3-min spin to remove insoluble residues, $50 \mu \mathrm{l}$ of the supernatant was incubated with $50 \mu \mathrm{l} \mathrm{cyclic}{ }^{3} \mathrm{H}-\mathrm{AMP}(0.5 \mu \mathrm{Ci} / \mathrm{ml}, 18 \mathrm{pmol} / \mathrm{ml})$ and 50 $\mu \mathrm{l}$ binding protein solution. After incubation at $4^{\circ} \mathrm{C}$ for $8 \mathrm{hr}$ and following the addition of $100 \mu \mathrm{l}$ charcoal suspension, the tubes were centrifuged for $3 \mathrm{~min}$, and $200 \mu \mathrm{l}$ of the supernatant was counted in scintillation fluid. All values reported were measured within the linear range of the assay.

\section{Results}

Proenkephalin gene expression is synergistically activated by membrane depolarization or A23187 with forskolin

Stable clonal lines expressing pENKAT-12 and the dominant selectable marker neomycin resistance were produced in rat pheochromocytoma $\mathrm{PC} 12$ cells (the PC12-F3 line) and rat C6glioma cells (the C6-D2 line). Stable clonal lines were used in order to perform multiple readily comparable experiments. The fold-induction of the proenkephalin gene in response to regulators in these clonal lines was similar to that observed with transient transfection of pENKAT-12, ruling out the possibility that the observed effects were an artifact of the integration site. Two different cell types were used in order to ensure that the results might be generalizable. Figure 1 shows the effects of forskolin, $\mathrm{KCl}$, and the calcium ionophore $\mathrm{A} 23187$ on expression of CAT activity under the control of the human proenkephalin promoter in PC12-F3 cells (Fig. 1A) and C6-D2 cells (Fig. 1B). As expected, forskolin, an activator of adenylyl cyclase, produced approximately a 6-fold induction of CAT activity over the controls in both cell lines. In contrast, treatment of cells with depolarizing concentrations of $\mathrm{KCl}$ or with the calcium ionophore A23187 produced no significant induction. However, when combined with forskolin, $\mathrm{KCl}$ and $\mathrm{A} 23187$ produced levels of expression significantly higher than those induced by forskolin alone. In PC12-F3 cells, depolarization produced more than a 5 -fold increase and calcium ionophore nearly a 4-fold increase over forskolin alone (Fig. 1A), and in C6-D2 cells, depolarization and calcium ionophore produced approximately a 2 -fold increase over forskolin alone (Fig. 1B).

Membrane depolarization causes voltage-sensitive calcium channels on cell membranes to open. To investigate the role of calcium entry in depolarization-induced activation of proenkephalin gene expression, we determined the effects of extracellular calcium on levels of expression in response to $\mathrm{KCl}$. By altering the electrochemical driving force on calcium, alteration of extracellular calcium concentrate should affect the amount of calcium that enters cells with depolarization. As shown in Figure $2 A$, the magnitude of the $\mathrm{KCl}$ effect is proportional to the extracellular calcium concentration over a wide range of concentrations. Similar results were seen with PC12-F3 cells (not shown). Because the media was not entirely depleted of calcium (to retain cell viability), $\mathrm{KCl}$ retained some activity even when no $\mathrm{CaCl}_{2}$ was added.

Blockade of calcium entry with verapamil had a marked inhibitory effect on depolarization-induced activation of the fusion gene. At the concentration of verapamil shown in Figure $2 B(15 \mu \mathrm{M})$, there was no statistically significant difference in forskolin-induced gene expression. Although more complete blockade of the effects of $\mathrm{KCl}$ could be achieved with higher concentrations of verapamil, such concentrations also affected forskolin-induced expression (not shown), suggesting the emergence of nonspecific effects at high concentrations of verapamil.

To characterize more fully the synergistic interaction of calcium with cAMP, we also examined the effects of fixed concentrations of A23187 (50 nM) and extracellular calcium (1.8 mM) on expression produced by a wide range of forskolin concentrations in PC12-F3 cells. Figure 3 shows log-dose-response curves for forskolin with and without A23187. The phosphodiesterase inhibitor 3-isobutyl-1-methylxanthine (IMX) $(0.5 \mathrm{mM})$ was added to achieve maximal levels of cAMP. Calcium entry had a significant synergistic effect on expression of CAT activity at all effective concentrations of forskolin. Calcium produced striking increases in expression even at maximally effective concentrations of the cAMP agonists. Higher concentrations of forskolin produced a decline in expression, presumably as a result of toxicity to the cells (not shown). 

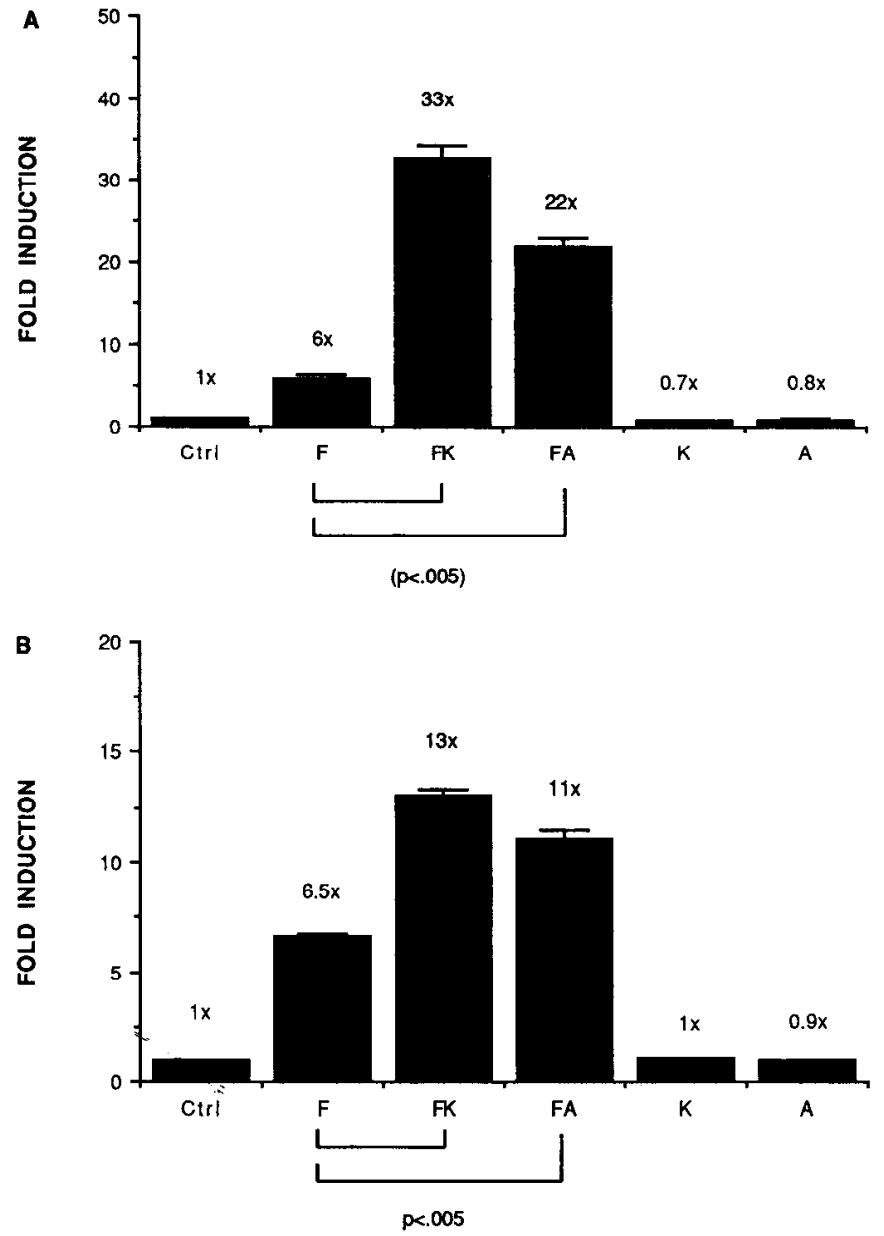

REGULATORS

Figure 1. Induction of CAT expression in response to regulators. $A$, PC12-F3 cells. $B$, C6-D2 cells. The final concentration of forskolin $(F)$ was $10 \mu \mathrm{M} ; \mathrm{KCl}(K), 40 \mathrm{mM}$; and $\mathrm{A} 23187(A), 500 \mathrm{nM}$; whether used singly or in combination. Fold induction represents induced CAT activity divided by control CAT activity after a 6-hr incubation with regulators. The extracellular $\left(\mathrm{Ca}^{2+}\right)$ was $1.8 \mathrm{~mm}$. For both $\mathrm{PC} 12-\mathrm{F} 3$ cells and C6-D2 cells ( $A$ and $B$, respectively), the effects of forskolin in combination with $\mathrm{KCl}$ or $\mathrm{A} 23187$ were significantly different from the effects of forskolin alone ( $p<0.005$ by Student's $t$ test; $n=6$ independent experiments; average and SEM shown).

\section{Effects of depolarization and A23187 are not mediated by cAMP, but may be calmodulin-dependent}

Because both $\mathrm{KCl}$-induced depolarization and $\mathrm{A} 23187$ require coactivation of $\mathrm{CAMP}$ to induce proenkephalin gene expression in C6-glioma and PC12 cells, we investigated the mechanisms by which the calcium and cAMP signal transduction pathways might interact to produce the observed synergy. An increase in cAMP levels has been shown to be required for voltage-sensitive calcium channels to open in response to depolarization in the neuroblastoma X glioma line NG108-15 (Freedman and Miller, 1984) and in GH3 pituitary cells (Armstrong and Eckert, 1987). Because calcium entry (and, by inference, opening of calcium channels) appears to be critical for the activation of gene expression by depolarization, this membrane effect of cAMP might explain the synergy of forskolin and $\mathrm{KCl}$. However, not only $\mathrm{KCl}$, but also the ionophore $\mathrm{A} 23187$ required cAMP in order

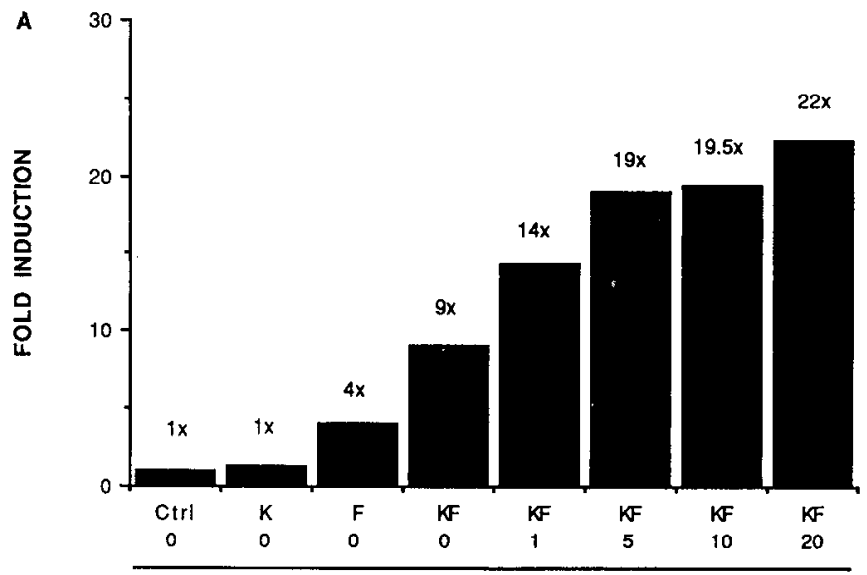

[CaCl2] (mM)

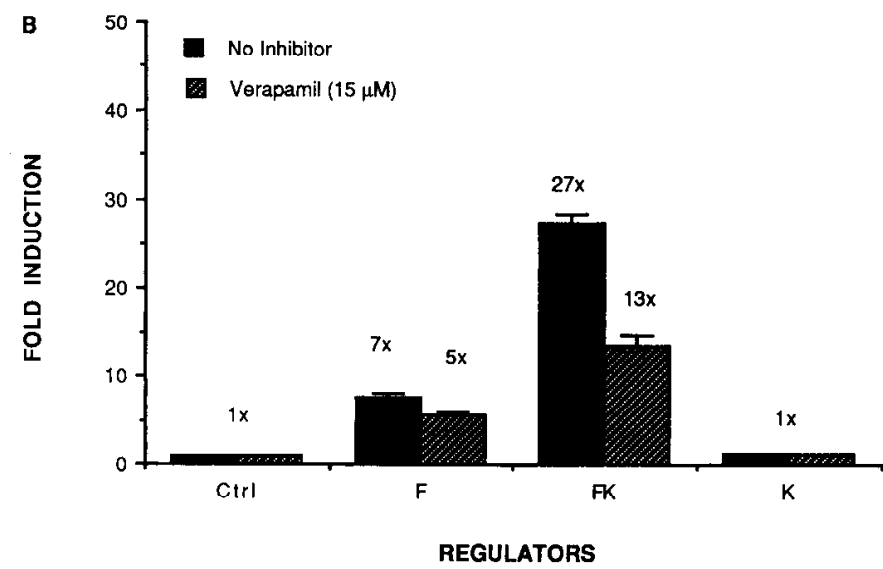

Figure 2. A, The effects of increasing extracellular calcium concentration on $\mathrm{KCl}$-induced expression of the pENKAT-12 in C6-D2 cells. Thirty min prior to adding regulators, standard media $\left(1.8 \mathrm{mM} \mathrm{Ca}{ }^{2+}\right)$ was replaced with low calcium media (made with calcium-free DMEM [Gibco] and $10 \%$ serum). Concentrations of $\mathrm{CaCl}_{2}$ added to the media are shown at the bottom of each bar in mM. K, $40 \mathrm{mM} \mathrm{KCl} ; \mathrm{F}, 10 \mu \mathrm{M}$ forskolin. Fold induction over control ( $\mathrm{ctrl}$; arbitrarily set at 1$)$ is shown above each bar. $B$, Effect of the calcium channel blocker verapamil on induced expression of pENKAT-12 in PC12-F3 cells. Cells were treated for $6 \mathrm{hr}$ with forskolin $(F), \mathrm{KCl}(K)$, or the combination in the presence or absence of verapamil (added 30 min prior to other compounds). Final concentrations: verapamil, $15 \mu \mathrm{M}$; forskolin, $10 \mu \mathrm{M}$; KCl, $40 \mathrm{~mm}$. Shown are the average and SE of 4 separate determinations.

to induce gene expression (Fig. 1, $A, B$ ). Because A23187 acts independently of voltage-sensitive calcium channels, even if cAMP-dependent phosphorylation of channels affects the magnitude of depolarization-induced gene expression, there must be additional sites of action for cAMP.

Crosstalk between the cAMP and calcium-dependent signal transduction pathways might also occur at the level of second messengers, protein kinases, transcription factors, or DNA regulatory elements. In order to rule out the possibility that depolarization and $\Lambda 23187$ were simply acting by increasing intracellular levels of cAMP, we measured cAMP levels by 


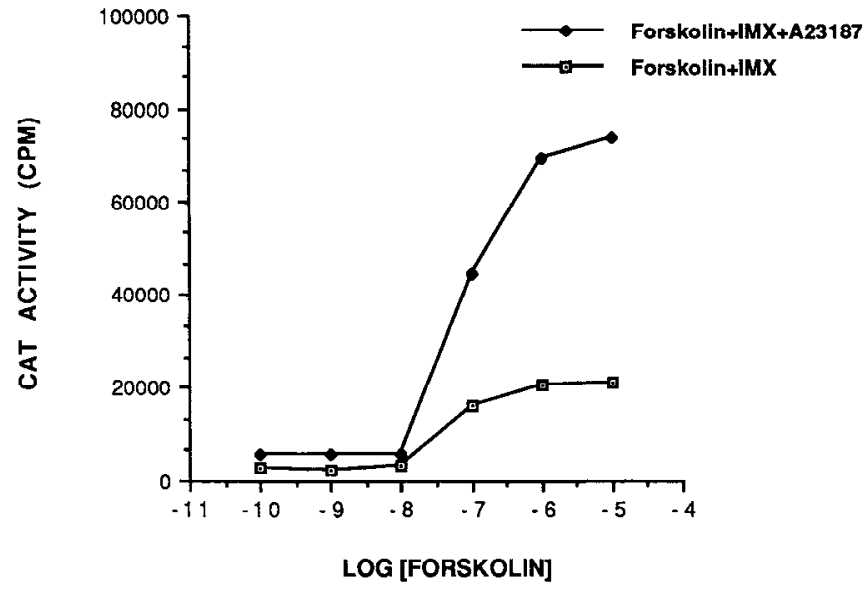

Figure 3. Synergy of the calcium ionophore A23187 with cAMP inducers forskolin and IMX in activating expression of the proenkephalin fusion gene in PC12-F3 cells. The abscissa shows the log-dose of forskolin. The ordinate shows net CAT activity (total CAT activity from samples minus a blank prepared from untransfected C6 cells). IMX $(0.5$ $\mathrm{mm}$ ) was present in all samples. The curves show the response of cells treated with forskolin and IMX in the absence (white squarcs with black dots) and presence (black diamonds) of $50 \mathrm{nM}$ A23187.

radioimmunoassay. A time course of cAMP generation was first determined; forskolin (final concentration, $10 \mu \mathrm{M}$ ) was added at time 0 to the media of C6-D2 cells and left there for the duration of the experiment. Intracellular cAMP levels were found to rise rapidly in response to forskolin (Fig. $4 A$ ) and were maximal at $30 \mathrm{~min}$, which corresponds to the time at which steady-state levels of correctly initiated mRNA from the proenkephalin promoter are rising most rapidly (not shown). The cAMP levels then declined, but remained elevated above baseline. We then measured the effects of $\mathrm{KCl}$-induced depolarization on cAMP levels. In C6-D2 cells, $\mathrm{KCl}$ had no significant independent effect on cAMP levels, nor a significant synergistic effect with forskolin at $30 \mathrm{~min}$ (Fig. $4 B$ ) or $6 \mathrm{hr}$ (not shown). A 30-min time point was also measured for PC12-F3 cells (Fig. 4C); $\mathrm{KCl}$ and $\mathrm{A} 23187$ had no significant independent or synergistic effects on cAMP. Therefore, the effect of depolarization and calcium on proenkephalin gene expression cannot be explained by synergistic increases in levels of cAMP.

To test the possibility that signal transduction to the nucleus converged at or beyond the level of the protein kinases, we used the calmodulin antagonists trifluoperazine and W7 (Hidaka and Tanaka, 1987). Inhibition of calmodulin should block the activation of calcium/calmodulin-dependent protein kinases but not cAMP-dependent protein kinase. Although trifluoperazine and $\mathrm{W} 7$ are not entirely specific, even at low concentrations, no more specific compounds were available. We tested both compounds in order to rule out the possibility that inhibition was due to an adventitious effect of one of the compounds. In PC12$\mathrm{F} 3$ cells, trifluoperazine $(20 \mu \mathrm{M})$ had no effect on activation of the proenkephalin fusion gene by forskolin but inhibited most of the effects of $\mathrm{KCl}$ and $\mathrm{A} 23187$ (Fig. $5 \mathrm{~A}$ ). At the concentration used $(20 \mu \mathrm{M})$, W7 had no effect on forskolin-induced expression and partially inhibited the synergistic effects of $\mathrm{KCl}$ and $\mathrm{A} 23187$ (Fig. 5B). More complete inhibition of the effects of $\mathrm{KCl}$ and A23187 was achieved with higher concentrations of $W 7$, but these data were not interpretable because, at higher concentrations, W7 becomes a nonspecific protein kinase inhibitor. One possible nonspecific action of both trifluoperazine and W7 even at low concentrations in inhibition of voltage-sensitive calcium channels (Harper, 1988). We therefore tested the effects of these compounds on both $\mathrm{KCl}$-induced expression, which is dependent on calcium channels, and on A23187-induced expression, which is not (Fig. 5, $A, B$ ). The data from use of these inhibitors is consistent with a role for calmodulin in calcium-mediated activation of gene expression. We did not test the effects of inhibitors of cAMP-dependent protein kinase in the present studies because it has already been established that expression of pENKAT-12 is absolutely dependent on the cAMP pathway (Grove et al., 1987; S. Hyman and M. Comb, unpublished observations). Taken together, the data suggest a model in which cAMP plays a permissive role for the actions of calcium on proenkephalin gene expression, and that the effects of calcium are independently mediated by a calmodulin-dependent pathway and therefore possibly by a calcium/calmodulin-dependent protein kinase.

CAMP-and calcium-inducible expression of the proenkephalin gene converge on a single DNA regulatory element

pENKAT-12, which is expressed in the PC12-F3 and C6-D2 cell lines, has previously been shown to be inducible by cAMP and phorbol esters (Comb et al., 1986). We have now demonstrated that it is inducible by calcium, as well. pENKAT-12 contains only 193 bases of human proenkephalin $5^{\prime}$ flanking sequence. To determine whether additional $5^{\prime}$ flanking sequences could also contribute to calcium responsiveness of the wild-type proenkephalin gene, we constructed a derivative of pENKAT -12 containing $3 \mathrm{~Kb}$ of proenkephalin 5' flanking sequence (pENKAT-3K). Stable C6-glioma cell lines expressing this plasmid were made and tested for response to cAMP, depolarization, A23187, and the combination. No additional contribution to calcium responsiveness was seen (data not shown). We conclude that the physiologically important sequences conferring calcium responsiveness on the proenkephalin gene probably reside within pENKAT-12.

pENKAT-12 contains a CAMP- and phorbol ester-inducible enhancer (Comb et al., 1986). This enhancer is comprised of 3 synergistically acting DNA elements: FNKCRE-1, ENKCRE2, and AP-2 (Fig. 6A; Comb et al., 1988; Hyman et al., 1989). The middle element, ENKCRE-2, contains the sequence CGTCA, which is the core consensus sequence for cAMP-regulatory elements (CREs) (Hyman et al., 1988). This ENKCRE-2 element is absolutely required for basal and cAMP-inducible transcription of the proenkephalin gene (Comb et al., 1988). In order to examine the role of this element in activation of the gene by depolarization and calcium entry, we constructed plasmids in which the entire enhancer was removed and then replaced by synthetic oligonucleotides containing the ENKCRE-2 sequence. The enhancerless parent plasmid pENKAT- $\Delta 72$, which lacks all 3 elements (ENKCRE-1, ENKCRE-2, and AP-2), gives no correctly initiated transcripts when stably expressed in C6 cells. It produces no CAT activity in response to forskolin or the combination of forskolin with $\mathrm{KCl}$ or $\mathrm{A} 23187$ when transiently transfected into multiple cell types including C6-glioma and PC12 cells (not shown). Another plasmid, pENKAT- $\Delta 84$, which contains the AP-2 element, but not ENKCRE-1 or ENKCRE-2, is also unresponsive to forskolin (Comb et al., 1986) or to forskolin combined with $\mathrm{KCl}$ or $\mathrm{A} 23187$ (not shown).

In the absence of the ENKCRE-1 element, a single copy of ENKCRE-2 is inadequate to produce a significant transcrip- 

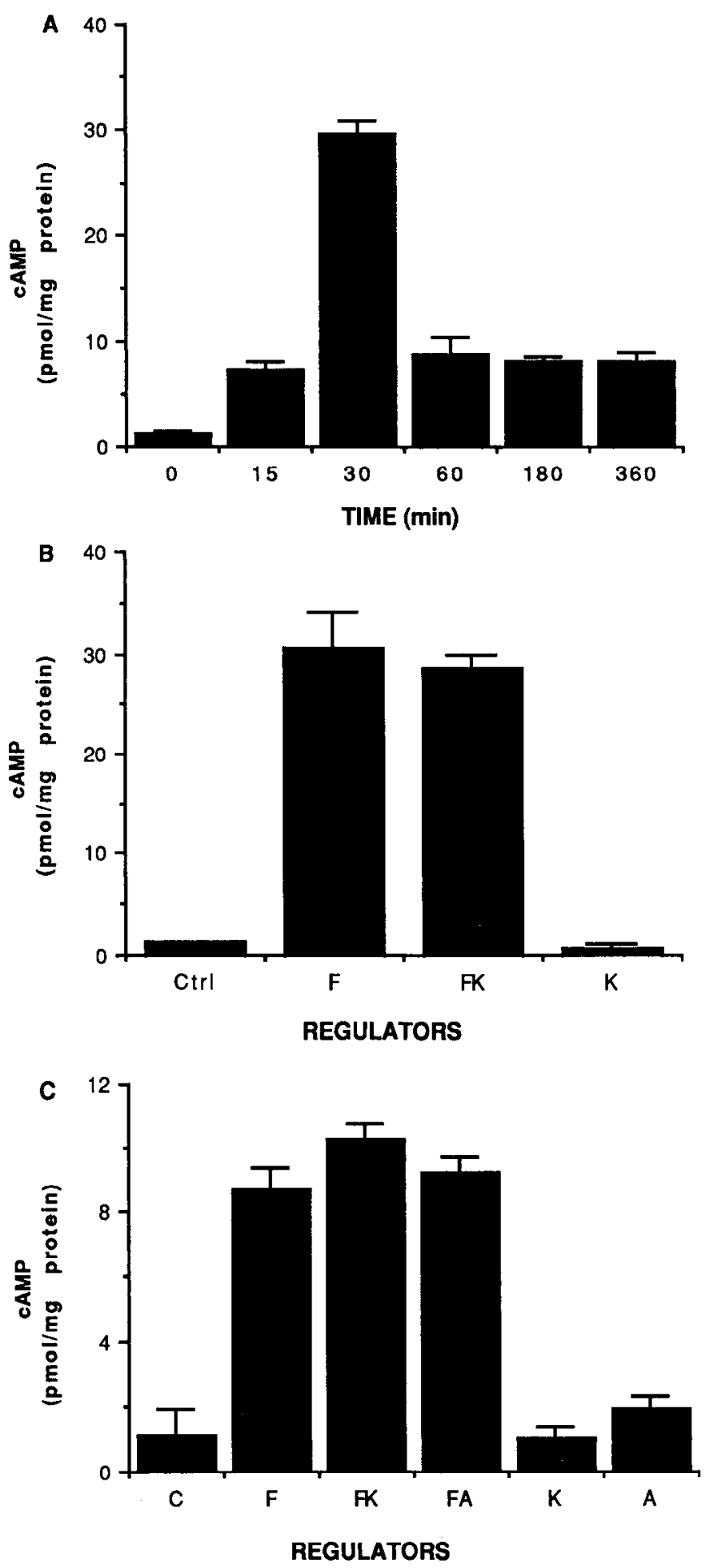

Figure 4. A, Time course of cAMP induction by forskolin in C6-D2 cells. Forskolin $(10 \mu \mathrm{M})$ was added at time 0 ; cells were harvested for assay at the times shown. The average and SEM are shown; 3 independent experiments were performed. $B$, cAMP levels in C6-D2 cells measured $30 \mathrm{~min}$ after the addition of regulators (average and SEM shown; 4 experiments). $C$, cAMP levels in PC12-F3 cells measured 30 min after the addition of regulators (average and SEM shown; 6 experiments). Final concentrations of regulators: forskolin $(F), 10 \mu \mathrm{M} ; \mathrm{KCl}(K), 40$ mм; $\mathrm{A} 23187(A), 500 \mathrm{~nm}$.
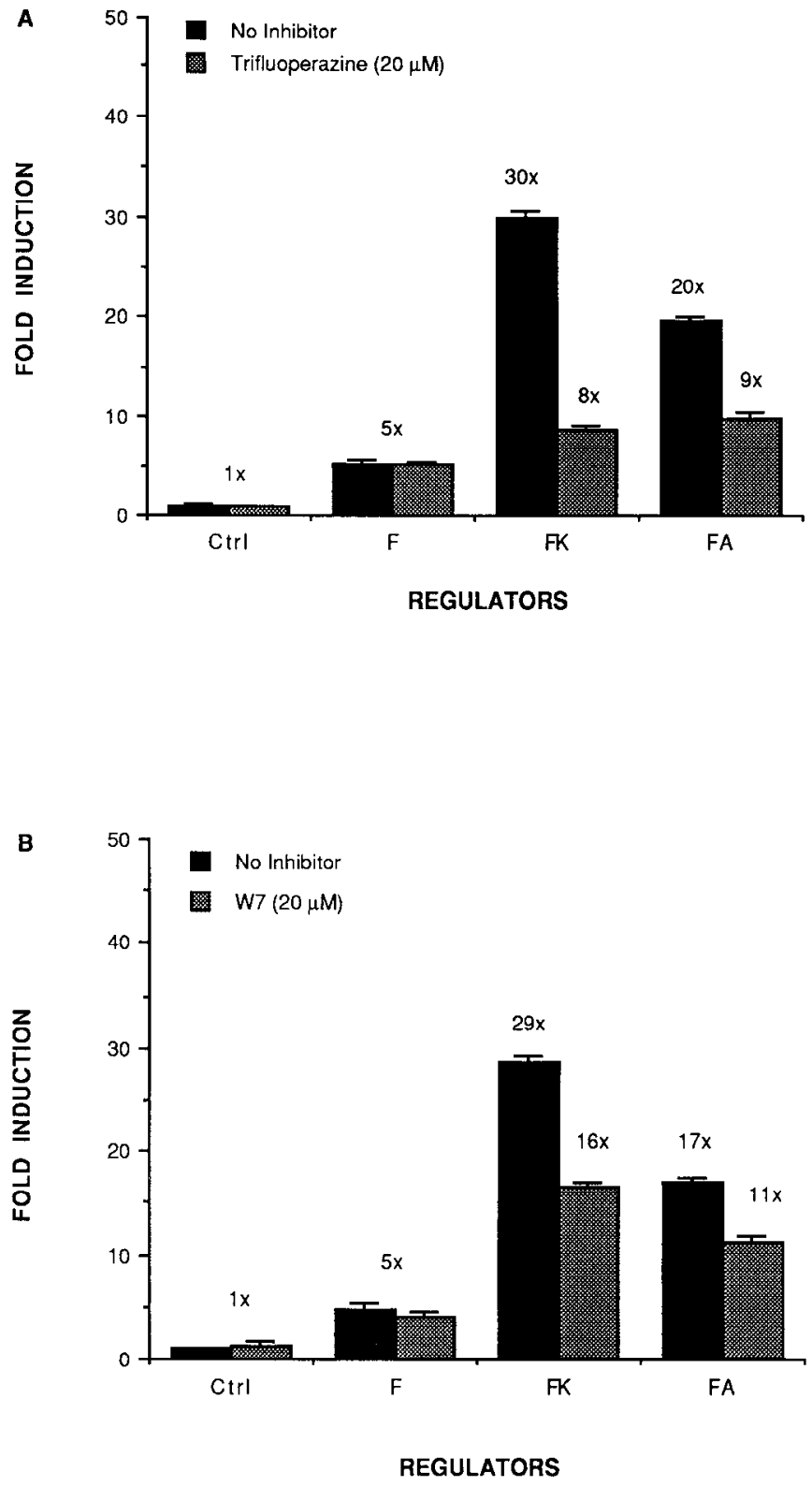

Figure 5. Effect of trifluoperazine and $\mathrm{W} 7$ on induced expression of pENKAT-12 in PC12-F3 cells. Trifluoperazine $(20 \mu \mathrm{M} ; A)$ and W7 $(20$ $\mu \mathrm{M} ; B$ ) were added $30 \mathrm{~min}$ prior to other regulators. Final concentrations of rcgulators: forskolin $(F), 10 \mu \mathrm{M} ; \mathrm{KCl}(K), 40 \mathrm{mM}$; A23187 $(A), 500$ nM. Neither trifluoperazine nor $W 7$ had an effect on expression induced by forskolin alone, but both significantly inhibited the synergistic response to $\mathrm{KCl}$ and $\mathrm{A} 23187$ (the effects of both inhibitors on both $\mathrm{KCl}$ and A23187 were significant by Student's $t$ test; $p<0.005 ; 4$ independent determinations; average and SEM shown).

tional response (Comb et al., 1988); we therefore constructed plasmids containing multiple copies of an oligonucleotide with the ENKCRE-2 sequence. The plasmid pENKCRE2-2 (Fig. $6 B$ ), which contains 5 copies of the ENKCRE-2 oligonucleotide, was tested in detail. Five independent lines of C6-glioma cells stably expressing pENKCRE2-2 were tested for response to cAMP and depolarization in order to rule out the possibility that the observed responses were dependent on integration site. Figure 7 shows the responses of the cell line $\mathrm{C} 6$-Cre2.2; this pattern of response was typical of the 4 other stable lines tested. Forskolin produces a robust induction; $\mathrm{KCl}$ produces no independent re- 
A

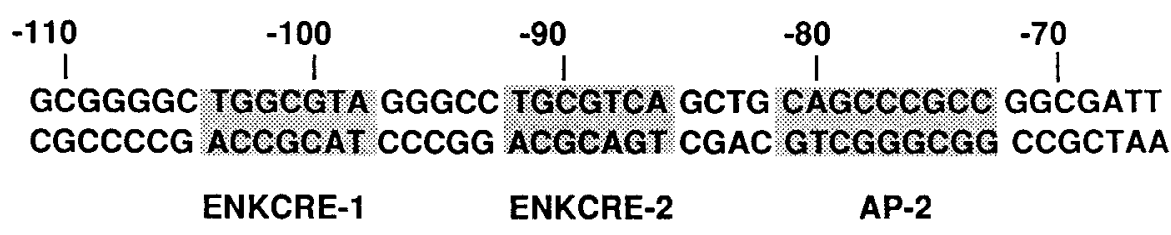

Figure 6. A, The sequence of the human proenkephalin enhancer. The individual elements that comprise the enhancer (shaded) were identified by extensive mutational analysis (Comb et al., 1988; Hyman et al., 1989). $B$, pENKCRE2-2. This plasmid was constructed in 2 steps from pENKAT- $\Delta 84$ (Comb et al., 1986), a derivative of pENKAT-12 in which the ENKCRE-1 and ENKCRE-2 elements were removed using a Pst I site at nucleotide -84. pENKAT- $\triangle 84$ was digested with Bssh II to remove the AP-2 element, and the AP-2 element was replaced with a Bgl II linker that does not bind AP-2 (Hyman et al., 1989). The resulting plasmid, pENKAT- $\Delta 72$, was digested with $\mathrm{Bgl} \mathrm{II,} \mathrm{and} \mathrm{oligonucleotides} \mathrm{con-}$ taining the ENKCRE-2 sequence with Bam HI cohesive termini were cloned into this site as concatamers.

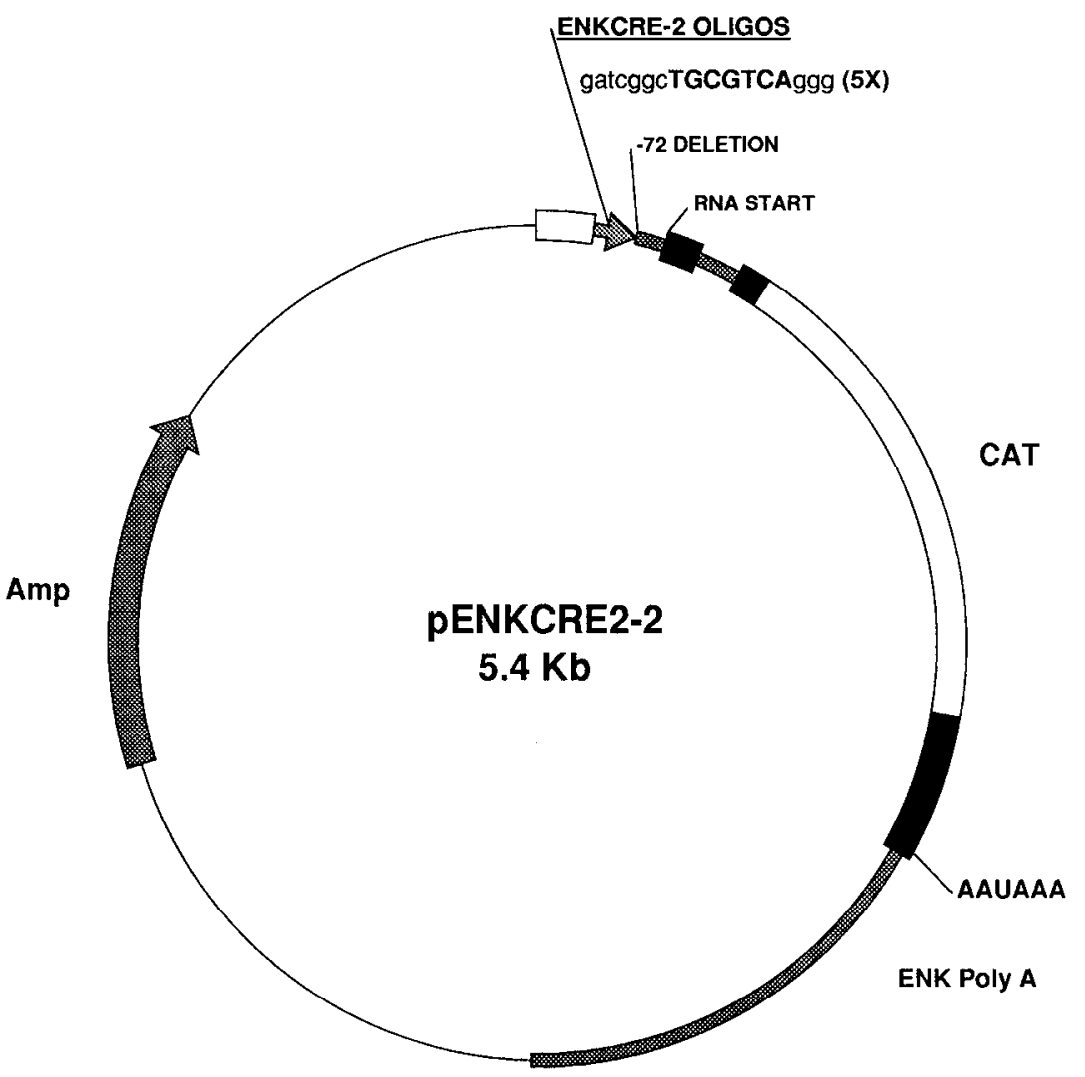

sponse, but in combination with forskolin produces approximately a 2 -fold increase over forskolin alone. Increasing the concentration of calcium from $1.8 \mathrm{~mm}$ (standard medium) to $20 \mathrm{~mm}$ produces a small increase in the forskolin response but a significant increase in the response of cells also treated with $\mathrm{KCl}$, consistent with what had been observed for pENKAT- 12 . Indeed, the pattern of response to regulators observed in C6Cre2.2 cells is quite similar to that seen for C6-D2 cells (Fig. 7; cf., Fig. $1 B$ ). The ability of multiple ENKCRE-2 elements to activate transcription in the absence of an ENKCRE-1 element suggests that multiple copies of one protein (or protein complex) bound in tandem can replace the protein/protein interaction between factors bound at the ENKCRE- 1 and ENKCRE-2 elements in the wild-type proenkephalin enhancer. Multiple copies of the ENKCRE-2 element are sufficient to confer responsiveness to both cAMP and depolarization on an inactive parent plasmid (pENKAT- $\Delta 72$ ). The activity of this element and the proteins with which it interacts is therefore sufficient for the activation of the proenkephalin gene by both cAMP and calcium.

\section{Discussion}

Intracellular signal transduction pathways

The data presented here represent an investigation into mechanisms responsible for regulation of gene expression by membrane depolarization. We have shown that depolarization-induced expression of pENKAT-12 increases with increasing concentration of extracellular calcium and is inhibited by the calcium channel blocker verapamil, consistent with calcium being the effector of the transcriptional response to depolarization. This interpretation is consistent with prior reports that calcium channel antagonists $\mathrm{D}_{600}$, verapamil and $\mathrm{Co}^{2+}$ (Kley et al., 1986) or low calcium media (Waschek et al., 1987) inhibit veratridineor $\mathrm{KCl}$-induced activation of proenkephalin gene expression in 
bovine adrenal chromaffin cells. These data suggest that one of the biological roles for voltage-sensitive calcium channels located on neuronal cell bodies may be in transduction of depolarizing signals to the nucleus to regulate gene expression.

In PC12 and C6-glioma cells, stimulation of the transfected proenkephalin gene by $\mathrm{KCl}$ or A23187 was not only synergistic with agents that increase levels of cAMP, but also absolutely dependent on them (Fig. 1, $A, B$ ). In contrast, in bovine adrenal chromaffin cells in primary culture, while activators of cAMP are robustly synergistic with depolarization in activating proenkephalin gene expression (S. Lewis and S. Hyman, unpublished observations), they are not absolutely required (Kley et al., 1986; Waschek et al., 1987; Kley, 1988). This difference between the transformed PC12 and C6-glioma cell lines and the primary cells was not an artifact resulting from use of a transfected fusion gene because the endogenous proenkephalin gene in C6-glioma cells is regulated similarly to the transfected gene (data not shown; PC1 2 cells do not express an endogenous proenkephalin gene). The reason for the absolute requirement for cAMP in the transformed cell lines but not in primary chromaffin cells is unclear, but it may involve cell-type specific differences in the activity of different components of the cAMP signal transduction pathway.

Neither $\mathrm{KCl}$-induced depolarization nor A23187 had an effect on cAMP levels; therefore, their effects on proenkephalin gene expression cannot be ascribed to superinduction of cAMP. Moreover, the effects of $\mathrm{KCl}$ and A23187 were inhibited by W7 and trifluoperazine, while the effects of forskolin were not. These data suggest that calcium, but not cAMP, might be activating gene expression through a calmodulin-dependent pathway. Interpretation of these data is limited by the nonspecificity of calmodulin antagonists currently available. A possible model is that cAMP, and therefore, presumably, cAMP-dependent protein kinase, has a permissive action in activation of proenkephalin gene expression, without which the calcium pathway cannot act.

\section{Synergy of calcium and cAMP}

Neurons express a wide variety of neurotransmitter receptors on their cell surface membranes, permitting them to respond to multiple extracellular signals. This diversity of extracellular signals may be transduced into different intracellular signals, including changes in membrane polarization or activation or deactivation of second-messenger systems. The integration of multiple intracellular signals is an important mechanism regulating cellular response: just as neurons summate excitatory and inhibitory postsynaptic potentials as determinants of reaching threshold for an action potential, it is likely that they summate the actions of multiple-signal transduction pathways as determinants of other cellular functions. For example, spatial and temporal integration of multiple signals appears to be involved in such phenomena as neuromodulation and long-term potentiation. The data presented here demonstrate that cells can integrate multiple signals to regulate gene expression, as well. We have previously reported that phorbol esters act synergistically with cAMP to activate proenkephalin gene expression (Comb et al., 1986; Hyman et al., 1989). Synergy of phorbol esters with cAMP has also been reported for the chorionic gonadotropin genes (Andersen et al., 1988). Here, we show an interaction between cAMP and calcium, as well; the magnitude of this interaction suggests that it is physiologically important (Гig. 3). This finding has potential implications for conceptualizing the

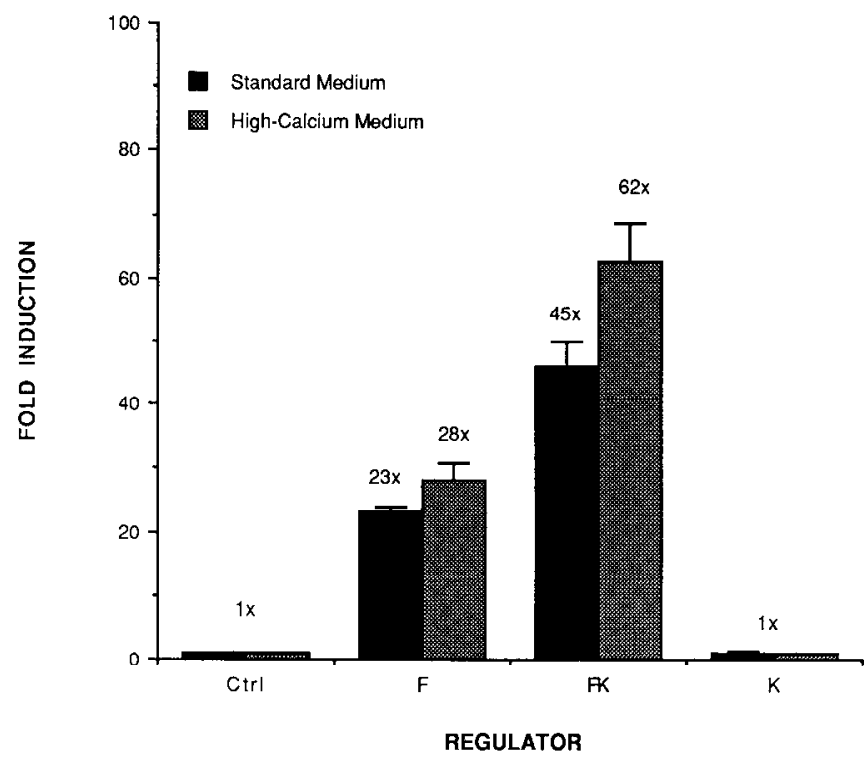

Figure 7. C6-Cre2.2 cells were treated for $6 \mathrm{hr}$ with forskolin $(F), 10$ $\mu \mathrm{M} ; \mathrm{KCl}(K), 40 \mathrm{mM}$; or the combination at 2 concentrations of extracellular calcium: standard $(1.8 \mathrm{~mm})$ and high $(20 \mathrm{~mm})$. Forskolin independently induces expression of this proenkephalin fusion gene. $\mathrm{KCl}$ produces no independent response, but when added to forskolin, it gives approximately a 2 -fold induction over forskolin alone. The combination of $\mathrm{KCl}$ and forskolin produces a significantly greater induction in high than in normal calcium media $(p<0.005$ by Student's $t$ test; 6 determinations; average and SEM shown), while forskolin alone does not.

interactions of excitatory neurotransmission and second-messenger pathways in models of neural plasticity such as long-term associative learning.

One model of transsynaptic activation of gene expression in which synergy may have particular relevance is the seizure model. Seizures have been shown to induce very high levels of expression of proenkephalin and a variety of other genes (Morgan et al., 1987; White and Gall, 1987; Saffen et al., 1988). Seizures represent the synchronous firing of many neurons and are therefore likely. They release multiple transmitters, including excitatory neurotransmitters such as glutamate, which would depolarize target neurons, and other neurotransmitters, such as peptides, which could activate the cAMP or protein kinase $\mathrm{C}$ pathways. The high levels of proenkephalin mRNA induction reported in response to seizures (White and Gall, 1987) are consistent with the synergistic mechanisms we have investigated here. The hypothesis, that synergistic activation of multiple intracellular messengers may control the level of gene expression in seizure and electrical stimulation models of gene expression, may be testable by the administration of selective pharmacologic blockers.

\section{Convergence of calcium and $c A M P$ responses on a common $D N A$ element}

We have shown that a concatamer of ENKCRE-2 elements confers response to both cAMP and calcium on a transcriptionally inactive parent plasmid. These data suggest a model in which a protein that interacts directly or indirectly with the ENKCRE-2 element can be activated by both protein kinase A and by a calcium-activated protein kinase, perhaps a calcium/ calmodulin-dependent protein kinase. Such a model would explain the synergy of cAMP with calcium. The data also suggest, 
however, that a cAMP-dependent process, perhaps phosphorylation by protein kinase $A$, is absolutely required for calciuminducible expression of pENKAT-12. In this model, subsequent phosphorylation of the same or an interacting protein by a calcium-dependent protein kinase would increase the efficiency of transcription initiations.

There is precedent for phosphorylation of a transcription factor by multiple protein kinases. The nuclear factor CREB, which has been shown to activate cAMP-inducible transcription of the somatostatin gene, dimerizes in vitro in response to phosphorylation by protein kinase $\mathrm{C}$ and stimulates transcription in vitro from a somatostatin-CAT fusion construct in response to phosphorylation by protein kinase A (Yamamoto et al., 1988).

Two calcium-responsive elements have been previously reported. One, a calcium-inducible regulatory region isolated from the rat genome (Lin et al., 1986), has no obvious homology to the ENKCRE-2 element. However, an element within the c-fos gene has also been reported to be calcium-responsive (Sheng et al., 1988). This element has the sequence TGACGTTT, containing the consensus cAMP regulatory sequence CGTCA on the complementary strand. This sequence is part of a region of the c-fos gene (nucleotides -72 to -54 with respect to the start site of transcription), which has independently been shown to confer transcriptional regulation by cAMP (Sassone-Corsi et al., 1988; Fisch et al., 1989). This is consistent with our finding that cAMP and calcium responsiveness can converge on a single DNA element, suggesting at least some cAMP-responsive elements may prove to be calcium-responsive elements, as well.

\section{References}

Andersen B, Milstead A, Kennedy G, Nilson JH (1988) Cyclic AMP and phorbol esters interact synergistically to regulate expression of the chorionic gonadotropin genes. J Biol Chem 263:15578-15583.

Armstrong D, Eckert R (1987) Voltage-activated calcium channels that must be phosphorylated to respond to membrane depolarization. Proc Natl Acad Sci 84:2581-2522.

Bartel DP, Sheng M, Lau LF, Greenberg ME (1989) Growth factors and membrane depolarization activate distinct programs of early response gene expression: dissociation of fos and jun induction. Genes Dev 3:304-313.

Black IB, Chikaraishi DM, Lewis EJ (1985) Trans-synaptic increase in RNA coding for tyrosine hydroxylase in a rat sympathetic ganglion. Brain Res 339:151-153.

Brown BL, Ekins RP, Albanoi JDM (1972) Saturation assay for cyclic AMP using endogenous binding protein. Adv Cyclic Nucleotide Res 2:265-267.

Comb M, Birnherg NC, Seasholtz A, Herbert E, Goodman HM (1986) A cyclic AMP- and phorbol ester-inducible element. Nature 323:353356.

Comb M, Mermond N, Hyman SE, Pearlberg J, Ross ME, Goodman HM (1988) Proteins bound at adjacent DNA elements act synergistically to regulate human proenkephalin cAMP inducible transcription. EMBO J 7:3793-3805.

Eiden LE, Giraud P, Dave JR, Hotchkiss AJ, Affolter H-U (1984) Nicotinic receptor stimulation activates enkephalin release and biosynthesis in adrenal chromaffin cells. Nature 312:661-663.

Fisch TM, Prywes R, Simon MC, Roeder RG (1989) Multiple sequence elements in the c-fos promoter mediate induction by cAMP. Genes Dev 3:198-211.

Fischer-Colbrie R, Iacangelo A, Eiden LE (1988) Neural and humoral factors separately regulate neuropeptide $Y$, enkephalin, and chromogranin A and B mRNA levels in rat adrenal medulla. Proc Natl Acad Sci USA 85:3240-3244.

Freedman SB, Miller RJ (1984) Calcium channel activation: a different type of drug action. Proc Natl Acad Sci USA 81:5580-5583.

Gall C (1988) Seizures induce dramatic and distinctly different changes in enkephalin, dynorphin, and CCK immunoreactivities in mouse hippocampal mossy fibers. J Neurosci 8:1852-1862.
Gorman C, Padamanbhan R, IIoward B (1983) High efficiency DNAmediated transformation of primate cells. Science 221:551-553.

Greenberg ME, Ziff EB, Greene LA (1986) Stimulation of neuronal acetylcholine receptors induces rapid gene transcription. Science 234: 80-83.

Grove JR, Price DJ, Goodman HM, Avruch J (1987) Recombinant fragment of protein kinase inhibitor blocks cyclic AMP-dependent gene transcription. Science 238:530-533.

Harper FH (1988) Stimulus-secretion coupling: second messengerregulated excytosis. Second Messenger Phosphoprotein Res 22:193318.

Hidaka $\mathrm{H}$, Tanaka $\mathrm{T}$ (1987) Transmembrane $\mathrm{Ca}^{2+}$ signaling and a new class of inhibitors. Methods Enzymol 139:570-582.

Howard B (1983) Vectors for introducing genes into cells of higher eukaryotes. Trends Biochem 8:209-212.

Hyman SE, Comb M, Lin YS, Pearlberg J, Green MR, Goodman HM (1988) A common trans-acting factor is involved in transcriptional regulation of neurotransmitter genes by cyclic AMP. Mol Cell Biol 8 : $4225-4233$.

Hyman SE, Comb M, Pearlberg J, Goodman HM (1989) Transcription factor AP-2 acts synergistically with the cyclic AMP inducible enhancer of the human proenkephalin gene. Mol Cell Biol 9:321-324.

Kanamatsu T, Unsworth CD, Diliberto EJ, Viveros OH, Hong JS (1986) Reflex splanchnic nerve stimulation increases levels of proenkephalin A mRNA and proenkephalin A-related peptides in the rat adrenal medulla. Proc Natl Acad Sci USA 83:9245-9249.

Kilpatrick DL, Howells RD, Fleminger G, Udenfriend S (1984) Denervation of rat adrenal glands markedly increases preproenkephalin mRNA. Proc Natl Acad Sci USA 81:7221-7223.

Kley N (1988) Multiple regulation of proenkephalin gene expression by protein kinase C. J Biol Chem 263:2003-2008.

Kley N, Loeffler J-P, Pittius CW, Hollt V (1986) Proenkephalin A gene expression in bovine adrenal chromaffin cells is regulated by changes in electrical activity. EMBO J 5:967-970.

Kley N, Loeffler J-P, Pittius CW, Hollt V (1987) Involvement of ion channels in the induction of proenkephalin A gene expression by nicotine and cAMP in bovine chromaffin cells. $J$ Biol Chem 262: 4083-4089.

LaGamma EF, White JD, Adler JE, Krause JE, McKelvy JF, Black IB (1985) Depolarization regulates adrenal preproenkephalin mRNA. Proc Natl Acad Sci USA 82:8252-8255.

LaGamma EF, White JD, McKelvy JF, Black IB (1988) Second messenger mechanisms governing opiate peptide transmitler regulation in the rat adrenal medulla. Brain Res 441:292-298.

Lewis EJ, Harrington CA, Chikaraishi D (1987) Transcriptional regulation of the tyrosine hydroxylase gene by glucocorticoids and cyclic AMP. Proc Natl Acad Sci USA 84:3550-3554.

Lin AY, Chang SC, Lee AS (1986) A calcium ionophore-inducible cellular promoter is highly active and has enhancerlike properties. Mol Cell Biol 6:1235-1243.

Lowry OH, Rosebrough NJ, Farr AL, Randall RJ (1951) Protein measurement with the Folin phenol reagent. J Biol Chem 193:265275.

Miller RJ (1987) Multiple calcium channels and neuronal function. Science 235:46-52.

Montminy MR, Sevarino KA, Wagner JA, Mandel G, Goodman RH (1986) Identification of a cyclic-AMP-responsive element within the rat somatostatin gene. Proc Natl Acad Sci USA 83:6682-6686.

Morgan JI, Curran T (1986) Role of ion flux in the control of c-fos expression. Nature 322:552-555.

Morgan JI, Cohen DR, Hempstead JL, Curran T (1987) Mapping patterns of c-fos expression in the central nervous system after seizure. Science 237:192-197.

Morris BJ, Feasey KJ, ten Bruggencate G, Herz A, Hollt V (1988) Electrical stimulation in vivo increases the expression of proenkephalin mRNA and decreases the expression of prodynorphin mRNA in rat hippocampal granule cells. Proc Natl Acad Sci USA 85:32263230.

Saffen DW, Cole AJ, Worley PF, Christy BA, Ryder K, Baraban JS (1988) Convulsant-induced increase in transcription factor messenger RNAs in rat brain. Proc Natl Acad Sci USA 85:7795-7799.

Sassone-Corsi P, Visvader J, Ferland L, Mellon PL, Verma IM (1988) Induction of proto-oncogene fos transcription through the adenylate cyclase pathway: characterization of a cAMP-responsive element. Genes Dev 2:1529-1538. 
Seed B, Sheen Y-Y (1988) A simple phase extraction assay for chloramphenicol acyltransferase activity. Gene 67:271-277.

Sheng M, Dougan ST, McFadden G, Greenberg ME (1988) Calcium and growth factor pathways of $\mathrm{c}$-fos transcriptional activation require distinct upstream regulatory sequences. Mol Cell Biol 8:2787-2796.

Waschek JA, Pruss RM, Siegel RE, Eiden LE, Bader M-F, Aunis D (1987) Regulation of enkephalin, VIP, and chromogranin biosynthesis in actively secreting chromaffin cells: multiple strategies for multiple peptides. Ann NY Acad Sci 493:308-323.
White JD, Gall CM (1987) Differential regulation of neuropeptide and proto-oncogene mRNA content in the hippocampus following recurrent seizures. Mol Brain Res 3:21-29.

Yamamoto KK, Ganzalez GA, Biggs WH, Montminy MR (1988) Phosphorylation-induced binding and transcriptional efficacy of nuclear factor CREB. Nature 334:494--498. 